\title{
Література:
}

1. Красиков М. «Строка, оборванная... пулей»? Судьба наследия Михаила Кульчицкого как зеркало нашей эпохи. URL: http://kharkovhumanit.narod.ru/Esse2.html.

2. Кульчицкий В.М. Вместо счастья: Стихотворения. Поэмы. Воспоминания о поэте. Харьков: Прапор, 1991. 270 с.

3. Маяковский В.В. Полное собрание сочинений: в 13 т. М.: Государственное издательство художественной литературы, 1958. Т. 7. Стихотворения, очерки. 1925-1926. 1958. 535 с.

4. Маяковский В.В. Полное собрание сочинений: в 13 т. М.: Государственное издательство художественной литературы, 1958. Т. 11. Пьесы, киносценарии. 1926-1930. 1958. 703 с.

5. Самойлов Д. Перебирая наши даты. URL: https://coollib.net/b/ 237451-david-samoylovich-samoylov-perebiraya-nashi-datyi/read.

DOI https://doi.org/10.30525/978-9934-26-039-1-25

\section{ФЕРДИНАНД ФОН ШИРАХ ЯК НОВА ПОСТАТЬ У СУЧАСНІЙ НІМЕЦЬКІЙ ЛІТЕРАТУРІ НА ЗАНЯТТЯХ З ОСНОВНОЇ ІНОЗЕМНОЇ МОВИ Й ПЕРЕКЛАДУ ЗІ СТУДЕНТАМИ ВІДДІЛЕННЯ НІМЕЦЬКОЇ ФІЛОЛОГІї}

\author{
Лисецька Н. Г. \\ кандидат філологічних наук, доцент, \\ дочент кафедри німецької філологіі \\ Волинського національного університету імені Лесі Украӥнки \\ м. Луиькк, Україна
}

Сучасна німецька література deutsche Gegenwartsliteratur [1; 2] представлена багатьма відомими іменами: Thomas Brussig, Elfriede Elinek, Felicitas Hoppe, Daniel Kehlmann, Bernhard Schlink, Ingo Schulze, Patrick Süskind, Uwe Tellkamp, Uwe Timm та ін. Проте до авторів початку третього тисячоліття належить також нове ім'я - Фердинанда фон Шираха. Для студентів факультетів іноземної філології твори відомого юриста можуть стати в пригоді при формуванні фахових компетентностей для поглиблення знань німецькомовного художнього дискурсу з фокусом на правову систему Німеччини, що свідчить про актуальність розвідки. Мета наукової праці - ознайомлення з творчістю Фердинанда фон Шираха. 
Фердинанд фон Ширах - нова постать у сучасній німецькій літературі. Це письменник, драматург та німецький адвокат. Уродженець Мюнхена (1964), він вивчає право в Боні та проходить референдаріат у Кельні й осідає у Берліні. Основною його спеціалізацією стає кримінальне право. Письменницьку діяльність Ширах починає у 45 років. Свій досвід і сучасний стан речей відомий адвокат розкриває у своїх творах, які миттєво підхоплюються молодими людьми, студентами юридичних факультетів Німеччини, а згодом читачами різних вікових категорій та професійних інтересів. Його книги стають бестселерами i представлені у 40 країнах світу. Це: «Verbrechen»//»Злочин» (2009), «Schuld»/»Вина» (2010), «Strafe»/»Поокарання» (2018) - книги кримінальних оповідань; «Der Fall Collini»/»Справа Колліні» (2011), «Tabu»/»Табу» (2013) - романи; «Die Würde ist antastbar»/»Гідність можна відчути на дотик» (2014) - збірка есе; «Die Herzlichkeit der Vernunft»/»Щирість розуму» у співавторсті 3 Александром Клюге (2017) - книга п'яти розмов про Сократа, Вольтера, Кляйста, політику, театральну виставу «Terror»; «Kaffee und Zigaretten»/»Кава i цигарки» (2019) - книга спостережень з власного життя та ін.

Ім'я Ф. Шираха асоціюється 3 високою культурою, майстерністю, точністю мовного вираження і сильною композицією: «Es sind kleine Meisterwerke darunter von enormer sprachlicher Präzision und Darstellungskraft» (Uwe Wittstock, Die Welt) [3]. Він любить бути критиком, його роботи допомагають глибше зрозуміти правову систему. Будучи адвокатом 3 кримінальних справ, Ф. Ширах вирішував складні життєві ситуації, які він брав за основу своїх сюжетів, а це означає, що читачі відчувають безпосередню близькість автора до зображених подій. 3.01.2021 p. у Німеччині відбулася прем'єра телевізійної драми «Feinde»/»Вороги» на першому каналі ARD. Одна історія подається у двох перспективах - 3 позиції поліцейського, комісара поліції Петера Надлера, та $з$ позиції захисника, адвоката Конрада Біглера (див. ARD Projekt Feinde (2021 p.)). У проєкті Ф. Ширах піднімає питання права i справедливості/die Frage des Rechtes und der Gerechtigkeit. Ключовою проблемою у розповідях Ф. Шираха постає Die Würde des Menschen ist unantastbar/Гідність людини недоторкана.

Жертвами в історіях Ф. Шираха є і жінки (Ausgleich, Einsam, Anatomie), і чоловіки (Freund, Geheimnisse, Justiz, Familie, Der Fall von Collini). Фердинанд фон Ширах у своїх творах наголошує, що у демократичній державі людина, іï права i свобода $\epsilon$ найбільшими цінностями. Провідними темами автора є Die Würde des 
Menschen/гiдність людини, Moral/мораль, Schuld/вина, Die Kenntnis des Rechtssystems/знання правової системи, Verbrechen/злочин, Strafe/nокарання, Die Würde des Menschen ist unantastbar/2iдність людини недоторкана, Recht und Gerechtigkeit/nраво і справедливість [3, 4, 5].

Розглянемо коротко оповідання «Kinder» збірки «Schuld» [3, с. 53-63]. Гольбрехт і Міріам мають порядну сім'ю. Гольбрехт любить джаз і мріє про дітей. Проте відбулося щось непередбачене. Учениця початкової школи звинувачує Гольбрехта у домаганні. Дружина вірить свідченням своєї учениці і рішенню судді й віддаляється від чоловіка. Гольбрехт відбуває весь термін покарання. Після звільнення 3 в'язниці він випадково бачить дівчину на вулиці Курфюрстендам, яка свідчила проти нього в суді. У нього виникає бажання ії вбити, він навіть переслідує iï по дорозі до театру, проте не може цього зробити. Натомість Гольбрехт приходить в адвокатське бюро і, під час розмови 3 дівчиною, його адвокатом з'ясовується правда. Дівчина, будучи школяркою, так сильно любила свою вчительку, ревнувала ії до чоловіка, що підмовила подругу і вигадала історію про домагання. Справу знову розглядають в суді і з Гольбрехта знімаються всі обвинувачування. Проте йому вже не повернути свою сім'ю і втрачені роки. Він вчиться 3 цим жити. На грошову компенсацію від держави Гольбрехт купує маленьку кав'ярню в Шарлоттенбурзі, де можна поласувати домашнім шоколадом та смачною кавою. Він живе 3 італійкою, яка його кохає. Деколи адвокат Гольбрехта заходить до нього на каву, однак про давню справу вони ніколи не згадують. Ф. Ширах зображує події ясно 3 притаманною йому глибиною деталей. Історії розгортаються в неочікуваному напрямку. Назва твору позитивно конотована, тому що діти викликають позитивні відчуття. Проте через дитячу примху несправедливо обвинувачено й засуджено героя твору. Чому так трапляється в суспільстві, що невинні мають відбувати покарання, а винних не засуджують: Der Unschuldige muss eine Freiheitsstrafe abbüßen. Der Schuldige wird nicht bestraft. Лексико-стилістичні засоби твору спрямовані на зображення деталізації і конкретизації подій: Holbrecht brachte am nächsten Tag die Unterlagen des alten Verfahrens; портрета дійової особи: Sie war eine junge Frau, Auszubildende im Gastgewerbe, Sommersprossen, nervös; юридичної сфери: sich zи seiner Schuld bekennen, die Wiederaufnahme des Verfahrens wurde zugelassen, Holbrecht wurde in der neuen Hauptverhandlung freigesprochen usw.

Твори Ф. Шираха пронизують своєю реалістичністю і відчуттям пошуку справедливості. Вони цікаві для всіх небайдужих людей, які хочуть віднайти правду і живуть за законами правової держави. Для 
України, яка знаходиться на шляху становлення демократичного суспільства, особливо актуальним $\epsilon$ ознайомлення 3 творами цього письменника, який у художній формі так витончено й лаконічно доносить до читача основні постулати правової держави та наголошує на проблемах і викликах сучасного суспільства.

1. Jeßing B. Neuere deutsche Literaturgeschichte. Tübingen: Gunter Narr Verlag. 252 S.

2. Zymner R., Fricke H. Einübung in die Literaturwissenschaft. Paderborn: Ferdinand Schöning Verlag UTB. 296 S.

3. Schirach F. Schuld. Stories. München : btb, 2017. 200 S.

4. Schirach F. Strafe. Stories. München : btb, 2018. 200 S.

5. Schirach F. Verbrechen. Stories. München : btb, 2017. 306 S.

DOI https://doi.org/10.30525/978-9934-26-039-1-26

\title{
«ПРИМАРА» ЛЕСІ УКРАЇНКИ: ВНУТРІШНЯ ОРГАНІЗАЦІЯ ТЕКСТУ
}

\author{
Мусій В. Б. \\ доктор філологічних наук, професорка, \\ завідувачка кафедри загального та слов'янського літературознавства \\ Одеський начіональний університет імені I. I. Мечникова \\ м. Одеса, Україна
}

Прозові твори Лесі Українки все частіше стають об'єктом уваги літературознавців. Це стосується і того оповідання (але, на наш погляд, точніше - етюду, віршу у прозі), якому призначено наші нотатки. Досліджуючи діалогічну природу наративу у прозі Лесі Українки, В.Г. Сірук розглядає «Примару» (а також «Сліпець», «Щастя», «Голосні струни», «Весняні співи») у контексті ліричної прози [4, с. 126], звертається до символіки образів змія-полоза, поводиря та погонича [5]. Стильові ознаки «Примари» - предмет студіювання Оксани Головій [Голов]. До того ракурсу, у якому ми розглядаємо цей твір Лесі Українки, ближче Галина Яструбецька, яка у своїх розвідках виходить 3 того, що художнє «слово як матеріал, з якого постає естетичний об'єкт, ніколи не $\epsilon$ арифметичним набором звуків / знаків i механічним відповідником речового образу світу» [7, с. 233], і звертаючись до енергії 102 